\title{
Effective Strategic Planning and Knowledge Management Effects on Organizational Performance Mediated by Dynamic Capability Towards Threats of Chemical, Biological, Radiology, and Nuclear (CBRN) Weapon
}

\author{
R.A. Nora Lelyana* \\ MABES TNI AL \\ Jakarta, Indonesia \\ *nora.lelyana@yahoo.com
}

\author{
S. Pantja Jati \\ Mercu Buana University \\ Jakarta, Indonesia
}

\author{
Willy Arafah \\ Universitas Trisakti \\ Jakarta, Indonesia
}

\begin{abstract}
This study aims to determine the extent to which the Resources-Based View (RBV) concept of Dynamic Capability plays a role in providing solutions to the performance of the Republic of Indonesia's Ministry of Defense. Dynamic capability acts as the formulator of general policy and the bearer of the national defense function in dealing with various threats including chemical, biological, radiological, and nuclear weapons (CBRN). Quantitative approaches with explanatory research will explain the causal impact of the Effective Strategic Planning and Knowledge Management variables on Organizational Performance mediated by Dynamic Capability. The analysis method used is the Structural Equation Model (SEM) with a sample of 163 respondents including high-ranking Indonesian army (TNI) officers and Colonel / Civil Servant as drafters of national defense policy. The results showed that Dynamic Capability is used as a new model of strategic planning in defense organizations. At the operational level, it is necessary to validate the organization which has the main task and function of coordinating various Ministries / Institutions outside of defense related to the procurement, storage, and use of CBRN material as big data as well as a form of preparedness. At the strategic level, it needs to create a work program and budget planning as a follow up to the Non-military of Defense strategic guide. The importance of a national agency to combat threats to the CBRN or its development to the Ministry of Defense reports to the President since it is responsible for monitoring the events and consequences of the threat study/analysis and synergies with the governmental and non-governmental organizations. This helps to mobilize national resources for defense purposes.
\end{abstract}

Keywords-effective strategic planning, threat-based planning, knowledge management, organizational performance, dynamic capability, and CBRN weapons

\section{INTRODUCTION}

The use of constantly evolving chemicals, biology, radiology, and nuclear energy, as well as technological advances in all areas that bring benefits, pose potential threats. This occurs when it is intended for hostile or used as a weapon for certain purposes. The threat of chemical and nuclear energy is more easily identified as a weapon. However, a long and comprehensive analysis has been performed by several experts to identify these weapons. Similar to the Covid-19 pandemic virus, the outbreak of bird flu or Middle East Respiratory Syndrome (MERS) and Severe Acute Respiratory Syndrome (SARS) is difficult to ascertain naturally, and the effects were great that the CBRN threat was known for mass destruction. Some serious cases include the nuclear bombings on Hiroshima and Nagasaki, chemical weapons in the Syrian war, and biological weapons of the Ebola virus in Africa.

The policy of the universal defense strategy has been established by law. The Ministry, as the bearer of the national defense mandate is facing various threats as stated in the 1945 Constitution, actually has the responsibility to face military and non-military threats, especially when misuse of these materials is intended for hostile purposes, it can already be categorized as CBRN armed threats.

Defense policies were relatively biased, since the ministry / TNI dominated the main assets of defense, while the strategy, 
which was exposed to non-military threats, was barely noticed. Furthermore, they are not completely comprehensive because the potential of resources for national defense as one of the important aspects of its universal system cannot be fully exploited. The R.I No. 23 of 2019, which regulates the National Resources Management for Defense was only issued on October 24, 2019, and did not meet the implementing regulations.

The establishment of Ministry of Defense CBRN Desk or work team facing chemical, biological, radiology, nuclear and material threats [1], various Biodefense seminars, socialization/training / discussion group forums related to CBRN, as well as active support from Ministry of Defense / TNI on Global Health Security Agenda (GHSA) is a concrete step in anticipating the abused threat of CBRN materials. Even the Ministry has set strategic guidelines for Non-Military Defense with Regulation of its Minister following the Republic of Indonesia No.19 of 2016. This guideline is in line with the Military Defense Doctrine (Tri Darma Eka Karma), and it is an effort to promote the relevant Institutions to immediately refer and elaborate it into a guideline for implementation/action plan. It also addresses the key roles and functions of each person as they are the engine of an integrated and comprehensive governmental action plan and its legal aspects. In its development, not all related Ministries / Institutions make this guideline a reference, which even makes it a priority work program and budget. This is because defense and security are only believed to be the duty of the National Armed Forces (TNI) and the Police Republic of Indonesia (POLRI).

This research aims to analyze the Organization Performance of the Ministry of Defense as the bearer of national defense function in dealing with the threat of CBRN weapons using effective strategic planning, knowledge management, and dynamic capability as intervening mediators to build a conceptual relationship between variables

Strategic Planning is an essential process in performing an organization's mission, and it provides a framework to decide on how to allocate organizational resources, address challenges and take advantage of opportunities that arise along the way [2].

\section{LITERATURE REVIEW}

\section{A. Effective Strategic Planning}

The greatest perception of the respondents in the Ministry of Defense was: "The development of non-military forces, especially in the face of threats from chemical, biological, radiation, and nuclear weapons". Furthermore, it needs to pay attention to the development of global and regional strategic environmental conditions and threat risk. This shows that the policymakers understand that in compiling development plans for Defense Force, the threat of CBRN weapons needs to pay attention to the lingstra development and threats risk as well as follow the stages of management functions. In addition, it needs to pay attention to interoperability aspects, communality, and integration between army.

\section{B. Knowledge Management}

Respondents know that CBRN weapons attacks will have a significant impact but the Ministry does not have guidelines, contingency plans/warning systems to overcome the threats yet.

\section{Dynamic Capability}

The perception of the dynamic capacity of the highest respondent lies in "The organization cooperates well with other parties in terms of innovation and Research and Development" while the lowest "originates from employee ideas".

\section{Organizational Performance}

The perception of the highest respondent is "The personal element is an asset in a defense organization". From this statement, it emerges that human resources should in principle be able to create good cooperation and collaboration between Work Units, the Army and between Ministries/institutions / agencies and be able to create creative and innovative value.

\section{E. Hypothesis Development Research}

In dealing with the threat of CBRN weapons at Indonesia's Ministry of Defense,

H1: There is a positive influence of Effective Strategic Planning on Dynamic Capability.

$\mathrm{H} 2$ : There is a positive influence of Knowledge Management on Dynamic Capability.

H3: There is a positive influence of Effective Strategic Planning on Organization Performance.

H4: There is an influence of Knowledge Management on Organization Performance.

H5: There is an influence of Dynamic Capability on Organization Performance.

H6: There is a positive influence of Effective Strategic Planning on Organization Performance mediated by Dynamic Capability.

H7: There is a positive influence of Knowledge Management on Organization Performance mediated by Dynamic Capability.

\section{METHODS}

The study uses a quantitative approach for hypothesis testing. The population consists of the leaders and staff of the Ministry of Defense with 163 samples using the judgmental sampling technique involving Echelon I Officials (Directorate General), Echelon II (Secretary of the Directorate General / Director) and Echelon III (sub-directorate head/division head/section head / Associate Analyst). The analytical method 
used is the Structural Equation Model (SEM), while the software used for structural analysis is LISREL 8.80.

\section{RESULTS AND DISCUSSION}

\section{A. Results}

The results of hypothesis test can be seen on table 1 .

TABLE I. HYPOTHESIS TEST

\begin{tabular}{|l|l|l|l|}
\hline \multicolumn{1}{|c|}{ Hypothesis t- } & Coef. & $\begin{array}{l}\text { t-cision } \\
\text { value }\end{array}$ & \\
\hline $\begin{array}{l}\text { H1: There is a positive influence of } \\
\text { Effective Strategic Planning on Dynamic } \\
\text { Capability }\end{array}$ & 0.24 & 2.79 & Supported \\
\hline $\begin{array}{l}\text { H2: There is a positive influence of } \\
\text { Knowledge Management on Dynamic } \\
\text { Capability in dealing with the threat of } \\
\text { CBRN weapons at the Ministry of } \\
\text { Defense of Indonesia }\end{array}$ & 0.38 & 4.20 & Supported \\
\hline $\begin{array}{l}\text { H3: There is a positive influence of } \\
\text { Effective Strategic Planning on } \\
\text { Organization Performance }\end{array}$ & 0.38 & 4.66 & Supported \\
\hline $\begin{array}{l}\text { H4: There is an influence of Knowledge } \\
\text { Management on Organization } \\
\text { Performance }\end{array}$ & 0.15 & 2.01 & Supported \\
\hline $\begin{array}{l}\text { H5: There is an influence of Dynamic } \\
\text { Capability on Organization Performance }\end{array}$ & 0.39 & 4.44 & Supported \\
\hline $\begin{array}{l}\text { H6: There is a positive influence of } \\
\text { Effective Strategic Planning on } \\
\text { Organization Performance mediated by } \\
\text { Dynamic Capability }\end{array}$ & 0.09 & 2.51 & Supported \\
\hline $\begin{array}{l}\text { H7: There is a positive influence of } \\
\text { Knowledge Management on Organization } \\
\text { Performance mediated by Dynamic } \\
\text { Capability }\end{array}$ & 0.15 & 3.31 & Supported \\
\hline
\end{tabular}

\section{B. Discussion}

According to research [3-5], the organization produced by strategic planning increases the financial performance and participation of members in the process including morale, motivation, employee commitment, and the formation of a general understanding of goals which will ultimately affect its dynamic capability. This is because it differs from ordinary/operational capabilities and it offers room for change, improvement, modification of resources to take advantage of existing opportunities [6]. Furthermore, it enables companies to capture new business opportunities [7]. It can be stated that when Ministry of Defense makes the development of the strategic environment and the threat of CBRN weapons as the basis for Planning the Non-Military Defense Force Development Strategy, paying attention to external and internal communication aspects and allocating a budget to improve the quality and quantity of human resources and infrastructure become necessary. The capabilities are dynamically strengthened through new concepts towards preparedness in national defense against the threat of CBRN weapons.

Knowledge is required to deal with environmental dynamics. Personal knowledge of the policy concepts developed by the Ministry of Defense, based on a variety of fgd/training/outreach activities as well as competency tests produced knowledge management about the awareness and massive impact of CBRN weapons attacks, and it influences dynamic capabilities [8].

Dynamic capability is defined as the ability to integrate, build, and reconfigure internal and external competencies to address environmental changes [9]. The base view of its resource can be updated continuously as an innovative response to environmental changes. Therefore, when human resources in the Department of Defense already have knowledge management, this will affect the ability to integrate, develop, and reconfigure internal and external capabilities to cope with environmental changes.

The highest respondents' perception of Organization Performance was "the HR element as an asset capable of implementing budget and time efficiency." Organizational performance is an indicator of the achievement level that can be achieved and reflects the success of strategic planning within the organization and is the result obtained from the behavior of its members [10].

The strategic planning in dealing with the threat of CBRN weapons in the Ministry of Defense needs to pay attention to the quality and quantity of human resources, therefore, they have creative and innovative elements as well as values, which create both external and internal collaboration between work units / Forces and K / L agencies. In addition, the human resource elements serve as an asset in the defense organization, perform the efficiency process, and increase the sustainability and legitimacy of the Ministry of defense in facing the threat of CBRN weapons.

The highest respondent's perception of organizational performance is "The elements of human resources are the strongest in defense organizations". Those that have creative and innovative values can create good cooperation and collaboration between work units as well as between ministries and institutions/agencies.

Knowledge is an important commodity [11] needed to transform resources into owned and interchangeable assets. Therefore, it can be concluded that increasing knowledge management related to the CBRN weapon threat will optimize the role of human resources as an asset in the organization of defense. The motivation of the Ministry of Defense increases and creates innovative value, the ability to work internally and externally since it is main sector of decision-makers in matters of defense policy.

Wernerfelt with the Resource Base Value (RBV) theory stated that an important factor to excel from competitors is the company's resources consisting of tangible and intangible forms (competence, technology, knowledge, skills, experience, and capabilities), which can be managed to survive [8]. However, its application is influenced by performance achievement factors including ability and motivation. Dynamic capabilities play an important role in creating value in a rapidly 
changing environment [12]. This shows that the Department of Defense's efforts to increase the capacity and human resources to handle CBRN weapons are very important, but are not being used optimally for change. Therefore, human resource ideas and innovations related to the preparation for the threat from CBRN weapons have not been fully exploited.

Effective strategic planning can help facilitate communication and participation, as well as accommodate differences in interests and values, help develop wiser decision making in problem-solving through meaningful analysis, and promote the implementation of success [13]. Organizational performance is an achievement tool that shows success based on the results achieved by members. In this case, dynamic capabilities and effective strategic planning play an important role as the ability of an organization to adjust its structural arrangements in creating value in a rapidly changing environment [12].

The Ministry of Defense will mobilize others to increase the readiness of facing the CBRN's weapons threat when formulators and policymakers related to non-military defense strategy planning (CBRN) have implemented the process, supported by dynamic HR capabilities and competencies as a mediating effect. Therefore, the human resources element serves as an asset that can perform efficiency processes and increase the sustainability and legitimacy of the Ministry of defense in the face of the CBRN weapons threat.

The influence of dynamic capability mediation between knowledge management and organizational performance is positive and significant. Therefore, the higher it is, the more it will strengthen the influence of knowledge management on organizational performance [14]. Its adaptability enables companies to make changes and progress, since it is a process for construction, placement, reconfiguration, and integration of institutional resources, as well as eliminating resources that do not provide a competitive advantage. The knowledge evolution cycle proposed [15] includes an accumulation of experience, articulation, and codification of knowledge as a dynamic capability process that will be generated by collective activities to learn and share knowledge to achieve company goals or increase performance.

Knowledge management related to the threat of CBRN weapons built by the Ministry of Defense will increase with the mediating effect of dynamic capability including the process of identifying new opportunities, collaboration with other parties in innovation and research and development. Furthermore, it involves a database system that maps employee competency levels, while utilizing ideas and human resource innovation maximally towards change. Therefore, the HR element as an asset of the defense organization can play a role as a leader and have the ability to partner with ministries of non-defense institutions. This will enhance collaboration and partnerships with various parties in facing the threat of CBRN weapons

\section{CONCLUSION}

Effective strategic planning and knowledge management have an impact on the organizational performance mediated by dynamic capacity. Furthermore, the seven hypotheses proposed are proven to be accepted. First, dynamic capabilities can be used as a new model in any strategic planning by defense organizations, since they act as mediators to improve effective strategic planning and knowledge management to deliver organizational performance as expected. Second, the Ministry of Defense as the leading sector at the strategic policy level prepares work programs and budgets in handling military threats. In addition, it designs budget work programs related to strategic planning as well as regulation in handling CBRN attacks and as a follow up to Law number 23 of 2019 on State Defense National Resources Management. Third, at the operational level, organizational validation is needed by forming the Directorate General of Defense Threats or developing the existing Ministry. It is charged with the responsibility of coordinating various expert institutions or agencies related to the procurement, storage, and use of CBRN materials, as a potential national defense force in handling threats. Fourth, it is important that the National CBRN Threat Management Agency reports directly to the President, because of the authorization to identify and analyze various nonmilitary threats from CBRN material.

\section{REFERENCES}

[1] Keputusan Menteri Pertahanan Republik Indonesia 2012 Nomor: KEP/434/M/VI/2012. Desk CBRN-e Kemhan / Tim kerja menghadapi ancaman kimia, biologi, radiologi, nuklir dan bahan peledak, 2012.

[2] The Enterprise Foundation. "The enterprise foundation, effective strategic planning: getting your organization focused and directed," 2020 .

[3] H.I. Ansoff, "The design school: Reconsidering the basic premises of strategic management," Strateg Manag J., vol. 12, pp. 449-61, 1991.

[4] D.W. Gerbing, J.G. Hamilton, and E.B. Freeman, "A Large-scale second-order structural equation model of the influence of management participation on organizational planning benefits," J Manage, vol. 20, no. 4, pp. 859-85, 1994.

[5] F.S. Berry and B. Wechsler, "State agencies' experience with strategic planning: Findings from a national survey," Public Adm Rev., pp. 15968, 1995.

[6] C.E. Helfat and M.A. Peteraf, "Understanding dynamic capabilities: Progress along a developmental path," Strateg Organ., vol. 7, no. 1, pp. 91-102, 2009.

[7] D.J. Teece, "Explicating dynamic capabilities: The nature and microfoundations of (Sustainable) enterprise performance," Strateg Manag J., vol. 29, pp. 1319-50, 2007.

[8] J. Barney, "Firm resources and sustained competitive advantage," J Manage, vol. 17, no. 01, pp. 99-120, 1991

[9] D.J. Teece, G. Pisano, and A. Shuen, "Dynamic capabilities and strategic management," Strateg Manag J., vol. 18, pp. 509-33, 1997.

[10] Moeheriono, Pengukuran kinerja berbasis kompetensi. Jakarta: Raja Grafindo Persada, 2012.

[11] H. Saint-Onge and D. Wallace, Leveraging communities of practice for strategic advantage. New York: Butterworth-Heinemann, 2003 
[12] R.P. Rumelt and D. Schendel and D.J. Teece, Fundamental issues in strategy. Fundamental issues in strategy: A research agenda. Boston, MA: Harvard Business School Press, 1994, pp. 9-47.

[13] J. Bryson, Strategic planning for public and nonprofit organizations (rev. Ed.). San Francisco: Jossey-Bass, 1995.
[14] A. Véronique and C. Bowman, "What are dynamic capabilities and are they a useful construct on strategic management?' Int J Manag Rev., vol. 11, no. 1, pp. 29-49, 2009.

[15] M. Zollo and S.G. Winter, "Deliberate learning and the evolution of dynamic capabilities," Organ Sci., vol. 13, no. 3, pp. 339-51, 2002. 